Лучицька М. $С$.

кандидат філологічних наук, старший викладач кафедри практики германських мов Кіровоградського державного педагогічного університету імені Володимира Винниченка

\title{
НАРАТИВ ДИТЯЧОГО СВІТУ ОПОВІДАННЯ Є. ГУЦАЛА «СКАЖЕНИЙ ЧОРНОБИЛЬСЬКИЙ СОБАКА»
}

У статті аналізуються особливості наративу оповідання С. Гуиала «Скажений чорнобильський собака». Крізь виокремлення форм нарації, щзо домінують, типів нараторів окреслюється особливе розуміння письменником дитячого світу, майже ідеального світу, 3 його чистотою, щирістю, високою духовністю, здатністю захищати та рятувати, розуміти один одного без слів, ичінувати щзиру дружбу.

Ключові слова: наратив, фокалізаиія, гетеродієгетичний екстрадієгетичний наратор, всевідний наратор, образ автора, голоси персонажів.

В статье анализируются особенности нарратива рассказа Е. Гуиало «Бешеная чернобыльская собака». Путём выделения доминирующих форм наррации, типов нарраторов передаётся особенное понимание писателем мира детей, почти идеального мира, с его чистотой, искренностью, высокой духовностью, способностью защищиать $u$ спасать, понимать друг друга без слов, иенить искреннюю дружбу.

Ключевые слова: нарратив, фокализачия, гетеродиегетический экстрадиегетический нарратор, всезнающий нарратор, образ автора, голоса персонажей.

The peculiarities of the narrative of the short story by E. Hutsalo"The Rabid Chornobyl Dog" are being analyzed in the article. By means of distinguishing the dominating forms of narration, types of narrators the peculiar author's understanding of the children's world is defined here, of an almost ideal world with its purity, sincerity, exalted spirituality and the ability to protect and save, to understand each other without any words, to value the sincere friendship.

Key words: narrative, focalization, heterodiegetic extradiegetic narrator, omniscient narrator, author's image, voices of the characters.

Прозові твори письменника-шістдесятника Є. Гуцала утвердились у літературі минулого століття як яскравий зразок емоційної, живої, сповненої настроїв та барв, оновленої прози, що однаково майстерно відображає не лише людину 3 ii суперечливим внутрішнім світом та непростою повоєнною реальністю чи реаліями часів другої світової війни, але й світ природи, роль якої у розкритті характерів сягає настроєтворчої.

Дослідженню творчого доробку митця присвячувались літературознавчі розвідки, літературно-критичні праці таких відомих науковців, як М. Жулинський, І. Дзюба, Л. Тарнашинська, Т. Гундорова, Н. Зборовська та багатьох інших. Жанрово-стильові особливості прози письменника 
аналізувались у різнопланових дослідницьких працях А. Гурбанської, В. Дончика, I. Захарчук, М. Логвиненка, Н. Ткаченко, М. Малахути, А. Шевченка та інших. Наративні моделі великої прози С. Гуцала, що вийшла в світ у 60-80-х роках XX століття, свого часу аналізувались у нашому дисертаційному дослідженні.

За умови існування великої кількості досліджень жанрово-стильових особливостей прози письменника, наратив його оповідань потребує вивчення та детального аналізу. Ми маємо на меті проаналізувати зразок малої прози Є. Гуцала з наратологічних позицій.

Об’єктом даного дослідження є оповідання «Скажений чорнобильський собака» 3 перевидання вибраних прозових творів письменника, що вийшло друком у 2014 році.

Предметом осмислення є форма нарації, що домінує в аналізованому оповіданні, тип наратора, фокалізація.

Теоретико-методологічною основою аналізу $є$ класифікація нараторів та наративних форм, розроблена Ж. Женеттом [Женетт 1998]. У процесі аналізу прози нами використовуються базові складові понятійного апарату наратології, викладеного у праці американського наратолога Дж. Прінса «A Dictionary of Narratology» [Prince 2003].

Погоджуючись із твердженням M. Жулинського про те, що С. Гуцало-прозаїк вирізняється «індивідуально-нюансовим реалізмом» [Жулинський 2005:6], наголошуємо: реалізм письменника має своєрідний романтизований ореол гуманізму, притаманний як повісті чи роману, так i зразкам малої прози митця. В. Дончик підкреслює, що у своїх прозових творах письменник - справжній «поет природи» [Дончик 1997:12]. А. Шевченко, підмічаючи особливу ліричність, мелодійність творчості Є. Гуцала, зазначає: «Він приніс із собою багато сонця, чистого неба, простору, живого різноголосся природи, запахущзої землі, а водночас $i$ високих почуттів, душевного тепла, людського милосердя» [Шевченко 2003:3]. Н. Ткаченко 
[Ткаченко 2005:7] підкреслює унікальну здатність митця показати людину так, щоб вона впізнала в художньому образі своє справжнє обличчя.

Зразки малої художньої прози Є. Гуцала, що увійшли до перевидання 2014 року, відкривають реципієнтові особливий мікрокосм - магію світу дітей. Кожне оповідання, маючи свого власного наратора, який різнопланово позиціонує себе стосовно дієгезису твору й матеріалізується в колоритних персонажах, об’єднане 3 іншим спільною особливістю - оповідь / розповідь ведеться крізь призму бачення дитини, тобто мова йде про наратив, інтродукований дитиною.

Наратив оповідання Є. Гуцала «Скажений чорнобильський собака» вирізняється розмаїттям форм нарації, представлених нараторами, які варіюються від типово гетеродієгетичного екстрадієгетичного [Женетт 1998], що наближається до образу автора в тексті твору, до всевідного наратораспострерігача, що веде розповідь крізь призму бачення дитини-хлопчика.

Гетеродієгетичний наратив із зовнішньою фокалізацією перманентно перейнятий дитячим світоуявленням із максималістським прагненням справедливості, щирістю та безпосередністю дитини. Всевідний наратор, що, за визначенням Дж. Прінса, так само займає позицію позазнаходження стосовно дієгезису твору ("A narrator who knows (practically) everything about the situations and events recounted ... Such a narrator has an omniscient point of view and tells more than any and all the characters know" [Prince 2003:68]), почасти розчиняється в дитячій свідомості, інтродукуючи реципієнтові романтизованореалістичну картину світу дітей.

Часом реципієнт ніби мандрує разом із маленьким хлопчиком, головним героєм Грицьком, та його неординарним другом - представницею світу тварин, старою собачкою Пальмою, в часі й просторі, потрапляючи у вир найемоційніших моментів такої незвичної дружби. Це досягається частим вдаванням автора-наратора до використання т. зв. ефекту ока камери («A technique whereby the situations and events conveyed (presumably) “just happen" before a neutral recorder and are transmitted by it» [Prince 2003:11]), 
який дозволяє візуалізувати події в розвитку 3 найтоншими деталями реальності дитячого світ.

Письменник, наближаючись до образу автора-наратора, як тонкий психолог влучно матеріалізує в розповіді всевідного наратора дитяче прагнення мати справжнього, вірного, некорисливого друга. У змалюванні дружніх стосунків хлопчика та собаки відчутний конфлікт двох діаметрально протилежних за ціннісними орієнтирами світів - світу дитини-героя та світу дорослих. Автор-наратор підкреслює прагматичність світу дорослих: цуценят, що ось-ось мають народитись, треба втопити, бо з них не буде користі; слід обмежити спілкування Грицька із собакою, оскільки Пальма - тварина із чорнобильської зони, покинута своїми хазяями, які рятувались від смертельної небезпеки, й сама $є$ небезпечною (ідеї старого діда Кирила). Такі важкі в емоційному сенсі факти стають відомі хлопчикові шляхом вплетення у наративну тканину аналізованого оповідання голосів персонажів, що експлікуюються, головним чином, в експресивному діалогічному мовленні (діалог матері Грицька з дідом Кирилом, діалог матері та сина).

Письменник, набуваючи ролі всевідного наратора, вдається до введення описів, що фіксують особливості зовнішності героїв (контраст потворного, скаліченого вигляду Пальми та іiі майже людського розуміння добра, iii щирості, своєрідної мудрості), яскраві пейзажні картини, що реалізують притаманну Є. Гуцалові взаємозалежність картин природи й відтінків настроїв людини, здатність транслювати зміни настроїв крізь пейзажні деталі та ін.

Граматична форма повістування, що домінує в творі - третя особа однини 3 превалюванням займенника «він».

Наратор матеріалізує світ чистої, відкритої дитини, яка не приймає жорстокості, байдужості, не здатна шкодити, має сили запобігти кривді, гармонійно співіснує зі світом природи.

Вдаючись до частого використання ефекту ока камери, всевідний наратор вимальовує деталі спілкування дитини зі світом природи та із яскравою його представницею: «Весна! А де Пальма? А вона виходить із-за комори й тюпає 
назустріч Грищькові ...» [Гуцало 2014:110]; «Грищько гладить долонею собаку поміж вухами, Пальма вдоволено примружується, шкіра на голові тремтить, вуха сіпаються, хвіст спроквола звивається по землі» [Гуцало 2014:111]; «... Брунатно-золотавий джміль бринить у повітрі, наче то брунатнозолотава грудочка застиглої, тужливо-радісної музики. Ось джміль рушає понад землею - $і$ вони слідом за джмелем через садок. Ось за садком джміль завмирає, гудучи, ц̌ вони також зупиняються. I щзе Пальма запитальнощзасливо поглядає на Грицьька здоровим блискучим оком...» [Гуцало 2014:111] та ін.

На перший погляд, звичайний хлопчик - Людина, здатна на вчинки. Саме він намагається врятувати майбутніх цуценят Пальми від неминучої загибелі, тікаючи в ліс: «... обоє не оглядаються на материн голос, бо обоє дружно біжать ... Здається ладна (Пальма - М. Л.) бігти з Грицьком на край світу, $i$ він з нею так само» [Гуцало 2014:118]. Людяність дитини підкреслюється автором-наратором також у їі ставленні до природи - перебуваючи в лісі, хлопчик «лікує» поранені берези, тим самим рятуючи i ïx від неминучої загибелі. Пік взаєморозуміння двох друзів - момент, коли Пальма допомагає своєму рятівникові - самостійно відшуковує пошкоджені дерева (розуміють один одного без слів). Спілкування дитини 3 собакою сягає телепатичного рівня - автор-наратор суцільним текстом подає плин думок Грицька про несправедливе ставлення дорослих до його друга, зосереджуючись на реакції розумної тварини: «Пальмі наче передаються його думки, собака раз $і$ вдруге киває головою, і водночас вигляд у неї якийсь винуватий. Винуватий, наче перед нею завинили. Винуватий, наче вона перед кимось завинила, насамперед - перед Грицьком. I він, відчуваючи гострий жаль, обіймає обома руками ї̈ за шию» [Гуцало 2014:125].

Сміливий, людяний, здатний на вчинки маленький філософ - передусім маленький хлопчик. Його лякає темрява, що насувається, він хоче їсти, водночас по-дорослому хвилюючись за зголоднілу Пальму, він ніяковіє перед рибалкою, якого вони зустріли на своєму шляху, розуміючи, що перебування 
дитини в лісі о такій пізній годині не викличе у подорожнього захват. Ці нюанси наратор вимальовує в експресивних діалогах (як в уявних: діалог хлопчика 3 собакою, так i в реальних: діалог Грицька 3 подорожнім), ніби оживлюючи голосами персонажів картини статичного плину часу в густому лісі.

Форма діалогу змінюється розпачливими рефлексіями під час змалювання раптового зникнення Пальми в сутінках. Дитина кличе собаку, вдаючись до тяжких роздумів щодо причин іiі зникнення. Всевідний наратор «відводить» дитину додому (типово дитячий вчинок - хлопчик підсвідомо сподівається на допомогу своєї матері).

Голоси персонажів знову матеріалізуються в експресивній діалогічній формі: автор-наратор вводить новий діалог матері 3 сином, 3 якого Грицько дізнається, що з Пальмою все гаразд - вона привела цуценят, що підсилює емоційність нарації дитячого розпачу й страху, викликаних хвилюванням за долю найкращого друга. Щирість хвилювання за друга утверджується у фінальних спостереженнях наратора: «... Грицько весь час прислухається: чи не чути чогось знадвору? Навіть уві сні прислухається. І сниться йому вві сні, як малесенькі руді иуцеенята граються за хатою на золотій пшеничній соломі. $A$ Пальма лежстьь неподалік від них - й щзасливо всміхається» [Гуцало 2014:133]. Автор-наратор не випадково наголошує на такому змісті дитячого сну: навіть на підсвідомому рівні думки дитини поруч з іï найкращим другом.

Отже, оповідання Є. Гуцала «Скажений чорнобильський собака»яскравий зразок творення живого наративу світу дитини, який базується на позиції позазнаходження наратора стосовно дієгезису твору, плин думок якого, водночас, невідривно пов'язаний зі світосприйманням головного героя. Мікросвіт старої Пальми та маленького хлопчика - образ-символ істинної дружби: обидва здатні без вагань прийти на допомогу один одному, захистити, коли $є$ загроза життю, врятувати від неминучої втрати. Світ дитини, візуалізований крізь ефект ока камери, оживлений голосами персонажів, матеріалізованими в експресивних діалогах - зразок доброти, духовності, 
здатності бути Людиною. Оповідання письменника вирізняється тонким гуманізмом, ненав'язливою дидактичністю, різнобарв'ям виражальнозображальних засобів, особливою романтизованою реалістичністю, інтелігентною справжністю.

\section{БІБЛІОГРАФІЯ}

Гуцало 2014 - Гуцало Є. П. Скажений чорнобильський собака: вибрані твори / Свген Пилипович Гуцало. - К.: Знання, 2014. - С. 109-133.

Дончик 1997 - Дончик Віталій. Подвижництво (до 60-ліття від дня народження Євгена Гуцала) / Віталій Дончик // Дивослово. - 1997. - № 1. C. $12-14$.

Женетт 1998 - Женетт Жерар. Фигуры. В 2-х томах / Жерар Женетт. Том 2. - М. : Изд-во им. Сабашниковых, 1998. - 472 с.

Жулинський Микола. Відкрився птахом, людям і рослинам ... Десять років без Євгена Гуцала / Микола Жулинський // Слово і час. - 2005. - № 8. C. $3-9$.

Ткаченко 2005 - Ткаченко Наталка. Спогад про Євгена Гуцала / Наталка Ткаченко // Літературна Україна. - 24 листопада, 2005. - С. 1-7.

Шевченко А. Феномен Свгена Гуцала. 3 книжки «День сонячного затемнення» /Анатолій Шевченко // Дивослово. - 2003. - № 3. - С. 22.

Prince 2003 - Prince G. A Dictionary of Narratology. Revised Edition / Gerald Prince. - Lincoln and London: University of Nebraska Press, 2003. - 126 p. 